\title{
A Study on the Heroic Traits of Odysseus
}

\author{
Li Yue \\ ${ }^{1}$ Department of Liberal Arts, Shanghai University of Medicine and Health Sciences, Shanghai, 201318
}

\begin{abstract}
Odysseus is a hero of Homeric Age. Similar to other heroes, Odysseus is gifted with strength and bravery. However, he also possesses several traits which cannot be found in most of the other heroes in the epics of that time. This essay analyzes the heroic traits of Odysseus and conduct a brief study on the historical background which produced such new traits, trying to find out clues of how the Greek unlocked the gate of intellect and civilization from Odysseus.
\end{abstract}

Keywords: Odysseus, Heroic traits, Homer's epics, Iliad, Odyssey

\section{Introduction}

Odysseus is a legendary Greek king of Ithaca and the hero in Homer's epic the Odyssey. He also plays a key role in Homer's Iliad and other works in the Epic Cycle. In addition, Odysseus is described as a hero full of resource in the Fall of Troy written by Quintus Smyrnaeus in the 4th century as well.

The two epics Iliad and Fall of Troy portray Odysseus as a resourceful Greek hero who always appears as a trusted counselor and adviser in the Trojan War. His most famous contribution during the war was devising the scheme of the Trojan Horse which decisively led to the victory of the Greek.

The Odyssey describes Odysseus journey towards home after the Trojan War and his efforts to restore the order of his Kingdom. On the way home from Troy, Odysseus suffered a lot, but most of the time the hero defeated his enemies and survived by his cunning intelligence and great determination. After returning to his hometown, Odysseus carried out his revenge scheme. With the help of Athena, Telemachus, Eumaeus and Philoteus, he killed all the suitors and restored his kingdom.

Compared with other heroes during the Homeric Age, Odysseus experiences more, therefore his view is broader and his character more complicated. In this essay, the heroic traits of Odysseus will be analyzed, especially focusing on the distinctive ones which cannot be found in other heroes, and finally try to sketch out the historical background which led to the emergence of such heroic traits in the epics.

\section{Analysis of the heroic traits of Odysseus}

Almost all the heroes of the Homeric Age are characterized by extraordinary strength. Odysseus is no exception. In Iliad, during the funeral games for Patroclus, Odysseus was involved in a wrestling match with Telamonian Ajax, as well as a foot race. With the help of the goddess Athena, he defeated the competitor and won the race. And in Odyssey, Penelope maneuvered the suitors into competing for her hand with an archery competition using Odysseus' bow. The man who could string the bow and shoot it through a dozen axe heads would win. Odysseus took part in the competition; he alone was strong enough to string the bow and shoot it through the dozen axe heads, thus became the winner.

\subsection{Odysseus has an independent mind instead of totally relying on the gods.}

In Odyssey, relationship between gods and human beings are not as close as that in Iliad and gods play a less vital role in earthen events. This means human beings are authorized with opportunities and rights to make decision and master their own life instead of totally relying on the gods and obeying their orders.

Odysseus is such an example. Faced with dilemma made by gods, He tries to make judgment and work out his own solution. In Book 5 of Odyssey, Odysseus suffered the terrific fury caused by Poseidon, Goddess Leucothea offered her veil. She asked him to swim to the Phaecian coast with her veil round his chest. However, Odysseus didn't adopt her advice immediately, instead, he thought in dismay, "this is only someone or other of the gods who is luring me to ruin by advising me to will quit my raft. At any rate I will not do so at present, for the land where she said I should be quit of all troubles seemed to be still a good way off. I know what I will do. I am sure it will be best." It is remarkable that he said so. Here the will of "I" begin to be independent from and challenge against that of the gods.

It is true that in Iliad the heroic Diomedes once challenged the immortal gods by wounding Ares and Aphrodite, but his courage is linked with the help and protection of Goddess Athena. While Diomedes challenged the strength of gods with the help of gods, Odysseus challenged the will of gods with his own mind and no other external power. So it could be said that Odysseus is the hero who brings the first light of independent intellect and sense in ancient Greek mythology.

\subsection{Odysseus fights with wisdom instead of conquering with strength}

In Odysseus we find the bud of reason and intellect which make him quite different from the other heroes. Instead of conquering with strength, Odysseus fights against his enemies and obstacles with wisdom.

Firstly, Odysseus's reason and wisdom is shown in the 10year-long Trojan War. He is not only a hero, but also a 


\section{International Journal of Science and Research (IJSR) \\ ISSN (Online): 2319-7064}

Index Copernicus Value (2013): 6.14 | Impact Factor (2014): 5.611

military strategist. In Book 19 of Iliad, the quarrel between Odysseus and Achilles is an example. When Achilles was informed of the death of Patroclus, he was in great fury and eager to revenge. He insisted that the sons of the Achaeans should fight without food and rest. Odysseus thought it was unwise, for the battle would be no brief one. He suggested that Achilles should send the army away and bid them have their meal first, for this would fill them with strength. This quarrel can be taken as a fight between two kinds of heroic traits: strength and wisdom. Although Achilles' strength contributes a lot to the victory at the beginning, it is Odysseus' wisdom which helps the Achaeans capture the Troy at last.

Secondly, Odysseus' wisdom is more apparently shown during his long voyage back home. The adventure on sea is quite different from the fight on the battlefront. The sea is just like a miniature society. Wisdom and trick are two of his best weapons. For example, in Book 9 of Odyssey, he cheated Polyphemus trickily that his name was "Noman", so when the Cyclopes asked Polyphemus who hurt him, the giant could only say "No man" hurt him. As Polyphemus said, Odysseus wounded him by fraud instead of by force. Compared with Achilles, Agamemnon and Hector who spend almost all of their life on the battlefield, Odysseus is more sophisticated and mature in mind. Through observing and thinking, Odysseus has a deeper understanding of the order of the world and the rules to survive in it. As Whitman Cedric says, through the arduous adventure, Odysseus becomes a man with richer experiences and greater wit to understand all the things. [1]

\subsection{The Odysseus is featured by patience and endurance instead of impetuousness}

Endurance is also a key factor in Odysseus' personality. Without this trait, maybe Odysseus' journey towards home would be much harder and his scheme of slaughtering all the suitors would not be successfully carried out.

From Odyssey we know that during Odysseus' adventure on sea, he humbled himself and pretended to be a helpless stranger when he met Alcinous, King of the Phaecians. Besides, he once became the prisoner of the monster and the companion detained by goddesses. All theseroles can hardly be associated with the traditional heroes. However, Odysseus gains the reputation as a hero of another type.

Odysseus' endurance and patience is fully embodied in his scheme of killing the suitors who pursue his wife Penelope and eat up his wealth. Odysseus left his homeland for 20 years. He missed his family members and his hometown extremely. But when he came back to his house, he had to humble himself to be an old beggar with tattered clothes in order to carry out his revenge plan step by step. During his stay at home, he was insulted and even beaten by the suitors. However, he restrained his fury and never revealed his real identity. Odysseus even warned his son Telemachus to forbear if he saw his disguised father being insulted. He instructed his young son to be forbearing and imperturbable not only because these traits would help them to accomplish the scheme of revenge at present, but also because these traits would qualify Telemachus to be the King of Ithaca in the future.

\subsection{Odysseus fights for common salvation as well as for personal glory}

"Glory" is a key word in ancient Greek mythology. It is guarded as firmly as the unshakable position of the gods and goddesses in the epics during Homer's age. To some extent, it is obligation and responsibility for gods and heroes to cherish the glory because for them, guarding their glory means pursuing the justice and keeping the order of the universe.

In Iliad, Achilles was in pursuit of glory. However, the glory pursued by Achilles was his personal glory. When King Agamemnon deprived him of his prize, he furiously rejected to fight any longer so as to maintain his glory without considering the fate of his country and his fellow soldiers.

Personal glory is not the only thing Odysseus strives for. $\mathrm{He}$ also strives for common salvation. This is mainly shown in his journey back home after the Trojan War. Odysseus is eager for salvation and he desires to get rid of the painful wandering life on sea. From him we find positive consciousness of self-salvation, which is rarely seen in other heroes of Homer's time. He also fights to save his companions and achieve common salvation. As Denton J. Snider points out, "That wisdom of his was employed, and that suffering of his was endured, not for his own good merely, but for the good of others."'[2] Snider views this as a hint of self-offering, which has not yet flowered but is certainly budding far back in old Hellas.

But Odysseus failed to save his companions at last: none of his fellows survived. Herein lies his limitation, in fact, it's the limitation of the entire Greek world. Because of the limitation of the epoch they lived in, those men lacked the reason and intellect which was needed for their salvation, while the heroic Odysseus also lacked the greater wisdom which was required for common salvation. Nevertheless, we have to admit that Odysseus' devotion to his companions mark a new development and bring additional credit to the Hero's character.

\subsection{Odysseus is a hero with more human nature than divine nature}

The heroes in Homeric Age are characterized by both human nature and divine nature; to some extent, maybe they are much closer to the latter one. They possess strong build and charming appearance; they fight bravely in pursuit of glory and remain fearless in face of death. They are simple and forthright in nature, similar to the gods and goddesses in ancient mythology, with characteristic of human beings at the stage of barbarism.

Odysseus, who is brave and more capable than other men on earth, embodies a sense of divinity as well. However, it seems that Odysseus shows more human nature compared with other heroes. In Book 11 of Iliad, when Odysseus faced the enemies alone, he said to himself in his dismay, "Alas,

\section{Volume 4 Issue 12, December 2015}




\section{International Journal of Science and Research (IJSR) \\ ISSN (Online): 2319-7064}

Index Copernicus Value (2013): 6.14 | Impact Factor (2014): 5.611

what will become of me? It is ill if I turn and fly before these odds, but it will be worse if I am left alone and taken prisoner." The monologue of Odysseus reflects his thoughts as an ordinary man. He is no god and he may fear and hesitate as common people, but as a hero his cowardice is replaced by bravery which encourages him to face his known or unknown fate fearlessly at last.

Odysseus is more secular than the other heroes. Although he was in great trouble, he insisted on eating and drinking first. He also entreated King Alcinous to help him to get home and he said he would be content to die if he might first once more behold his property, bondsmen, and all the greatness of his house. His needs and desire were close to those of ordinary people. It can be said that Odysseus is a representative of heroism featuring survival while Achilles a representative of heroism featuring glory.

Odysseus marks the approaching of a new heroic age. The hero descends from the divine alter and appears closer to the ordinary men. Gods are no longer the only factor which influence and decide the fate of humans. Human's selfconsciousness is awakened and heroes with traits of ordinary people step onto the historical stage.

\section{Study on the historical background producing Odysseus' heroic traits}

Homeric Age refers to the period from 12th century B.C. to the end of 9th century B.C. in ancient Greek. The period features Greek's transition from the later stage of clan society to the slave society and from a barbarous age to a slightly civilized age. During this period, many changes took place in different aspects of the society. The new heroic traits in Odysseus are associated with or embody these changes.

First and foremost, in terms of social and economic system, agriculture, handicraft and trade all underwent primary development during this age; and the bud of slave-owning economy thus appeared. In the epics, husbandry, fertilizing and irrigation are always mentioned. Apart from bronze ware, people began to use ironware. In the manors of some kings, there were cornfields, vineyards and pasture as well. All these show that the agriculture and animal husbandry had developed to a relatively high level at that time. Moreover, the handicraft industry began to divide further into iron smelting industry, ceramics making industry and textile industry. Weapons such as iron arrows, bows and war chariots were finely made. The description of the manufacture of Achilles' shield in the epic, although exaggerated, yet reflects the high level of the craft in weapon making to some extent.

The development of productivity and social division of labor directly led to the polarization between the rich and the poor. It is described in the epics that some of the kings owned fertile land, vast cornfield and vineyard. However, the ordinary people including farmers and handicraftsmen possessed far less wealth. Some even became slaves or beggars; they labored in the manors of military commanders, or wandered in the city or countryside, begging door by door.
Then, the polarization between the rich and the poor caused the emergence of class and the complication of social relation. This is reflected in two aspects: Firstly, the noblemen began to fight over the private property. The fight between Odysseus and the suitors was such an example. Secondly, the conflict between the slave holders and the slaves had emerged. Sometimes the slave holders might kill the slaves without any definite reason. For example, Odysseus suspected some of his salves had betrayed him and gone over to his enemies, thus he killed all of them cruelly with his son. The complication of social relationship brought more distrust and wariness to the society.

Odysseus' suspicion, his cunning intelligence as well as his efforts in restoring the order of Ithaca, are all the results of the social transition especially the complication of the interpersonal relationship. How to survive and win a place in the more complex society? In finding the answer to this question, there emerged the buds of reason. Therefore, Odysseus' heroic traits reflect the universal characteristics of the Homeric Age.

At the same time, the improvement of social productivity is inevitably accompanied with the progress of human's cognitive ability. In a clan society, people lacked the analyzing and summarizing abilities required to distinguish and conclude the phenomenon they observed. Furthermore, they could not understand the association and interaction of different things. However, the Homeric Age marked the transition from clan society to slavery society. With the development of productive forces, human's cognitive skills also improved. Their knowledge about the nature, the society and the human relations was enriched correspondingly. The barbarous culture of primitive tribes gradually shifted to the civilized culture of new societies; and the deepest influence of this shift was the awakening of human beings. Just as what was said by Odysseus, "I know what I will do. I am sure it will be best." The human beings got rid of the primitive mind and established their independent status before the nature and the gods. With the emergence and development of selfawareness, people began to think about themselves and the whole world in a more comprehensive way.

Last but not least, the Homeric Age is an age in which the hero system climbed to climax and then gradually stepped to termination. It is also an age in which the sign of civilization popped out now and then and the mythologies intertwined with the buds of reason. The epics show the light of intellect to some extent, but there are far more trace of superstition and fatalism between the lines. During the Homeric Age, people lacked enough wisdom to explain all the natural phenomenon, therefore, they explained these phenomenon by the fate and the existence of gods. Even Odysseus had to rely on the help and prediction of gods to fight with the nature sometimes. As is said above, Odysseus' limitation is not his individual limitation, but the limitation of the whole Greek during the Homeric Age. 
Notes:

[1] Whitman Cedric. Homer and the Heroic Tradition[M]. Cambridge: Harvard University Press, 1958 :175

[2] Denton J. Snider. Homer's Odyssey: A Commentary[M]. Chicago: The Sigma Publishing Co.1895: 5

\section{References}

[1] Homer. The Iliad. Translated by Samuel Butler[M]. 20116-29. http://classics.mit.edu/Homer/iliad.html.

[2] Homer.The Odyssey.Translated by Samuel Butler[M].2011-6-29. http://classics.mit.edu/Homer/odyssey.html.

[3] Li Tiangu.The History of Ancient Greek[M].Gansu: Lanzhou University Publishing House, 1991. 